\title{
VLIV CESTOVNÍHO RUCHU NA SOCIOEKONOMICKÉ A ENVIRONMENTÁLNÍ PROSTŘEDÍ MALTY: VNÍMÁNÍ MLADÝCH
}

\author{
Aneta Krajíčková
}

\begin{abstract}
With the increasing number of tourists in destinations, not only positive influences, but also increasingly negative impacts of tourism, which can be classified into environmental, economic, social and cultural areas, appear. In extreme cases, overtourism or tourism-phobia may occur in the destination. The impact of tourism on the inhabitants of the destination and its evaluation and understanding are key inputs for its sustainable development. This paper focuses on the perception of the impact of tourism on the socio-economic environment of Malta with a target group of younger than 26 for a questionnaire survey carried out during July 2018. The data processed from 93 questionnaires mainly shows a negative impact on the environmental and economic and positive impact on the social and cultural group and point to Malta's dependence on tourism.
\end{abstract}

Keywords: impacts of tourism, Malta, overtourism, perception of tourism

\section{Úvod}

Cestovní ruch je jedním z nejrychleji rostoucích odvětví se signifikantními ekonomickými, sociálními a environmentálními vlivy po celém světě. Jeho růst a udržitelný management jsou výzvou pro mnoho destinací. $\mathrm{V}$ posledních letech informují média o místech, která jsou konfrontována s problémem př́lišné intenzity turismu a overcrowdingu. $\mathrm{S}$ tím, jak těchto destinací přibývá, vznikly i nové termíny overtourism a tourism-phobia (Weber et al., 2017). Overtourismus je možné jednoduše popsat jako situaci, kdy je v destinaci př́liš mnoho turistů. Místní, hostitelé, návštěvníci nebo hosté pocit'ují, že kvalita zážitku, který jim destinace nabízí, nebo kvalita a standardy místního života jsou negativně ovlivněny (Koens, 2018). Společně s tím dochází, nebo může docházet, $\mathrm{k}$ nenávratnému ničení kulturního, př́rodního a sociálního bohatství, kterým daná destinace disponuje (Geng Ging-Chi et al., 2017; Dowling, Newsome, 2017). Tourism-phobia odkazuje na sociální nespokojenost $\mathrm{s}$ danou situací, organizaci kampaní, petic a protestů za účelem omezení počtu, př́istupu a regulace chování turistů (Milano, 2017). Na druhé straně přináší cestovní ruch benefity, jako jsou tvorba pracovních míst, zlepšování infrastruktury, generování př́ijmů, zlepšení ekonomické struktury regionu nebo podpora podnikání (Inkson, Minnnaert, 2014). Tento článek se věnuje cestovnímu ruchu Malty a především vnímání vlivu turismu na její socioekonomické prostředí. Prostřednictvím dotazníkového šetření 
je ukázaný pohled mladých do 26 let na současnou situaci a problémy, které cestovní ruch přináší.

\section{Teoreticko-metodická východiska}

\section{Vnímání cestovního ruchu místními}

Jedním z hlavních prvků nejen overtourismu je vztah mezi místními a turisty. Pochopení postojů a vnímání cestovního ruchu místními obyvateli je základem pro udržitelný rozvoj bez ohledu na jeho formu v libovolné destinaci (Gursoy, Chi, Dyer, 2010), stejně jako pro ř́zení kritických aspektů, které rozvoj turistického průmyslu přináší (Lawson et al., 1998). Zjednodušeně lze říci, že pro všechny destinace je úspěch stejně jako udržitelnost rozvoje cestovního ruchu závislá na přijetí turistů a $\mathrm{s}$ turismem souvisejících plánů místní komunitou (Bimote, Faralla, 2016). V počátcích cestovního ruchu byl důraz kladen na uspokojování potřeb turistů, nicméně později se pozornost upírala i směrem k místním obyvatelům a turismus začal být vnímán jako sociokulturní fenomén, ve kterém probíhá interakce mezi místními a turisty (Castillo Canalejo, NúñezTabales, Sanchez, 2016, Klufová, Šulista, 2018). Např. práce Stydlis, Key a Vijazan nebo Lee (in Al Rawabi et al., 2017) potvrdily, že jedním z klíčových indikátorů udržitelnosti destinace je míra, do jaké se místní obyvatelé angažují a podporují cestovní ruch.

Vnímání cestovního ruchu a jeho rozvoje v průběhu času nezůstává konstantní. Podle Dexey Irrindexu je možné předpokládat, že v počátku rozvoje budou místní turismus spíše podporovat, nicméně jejich vztah se bude až obracet proti, pokud negativní efekty převáží ty pozitivní (Reisinger, 2009). Vliv mají také socioekonomické charakteristiky rezidentů jako je pohlaví, věk, disponibilní př́ijem nebo vzdělání (Gonzales, Coromina, Galí, 2018).

Ačkoli je cestovní ruch vnímán jako činitel přispívající k růstu a větší prosperitě (Wall, Mathieson, 2006), ozývají se i kritické názory, díky kterým se zviditelňují problémy, jež pro hostitelské komunity prrináší. Velká část prací na toto téma se shoduje, že vlivy cestovního ruchu jsou vnímány hostitelskou komunitou $\mathrm{v}$ kontextu př́nosů a nákladů, které je možné klasifikovat do relativně samostatných typů nebo kategorií: ekonomické, environmentální a sociální, s tím, že sociální dělí někteří autoři na skupiny kulturní a sociální (Andereck et al., 2005). Sociální skupina zahrnuje prvky veřejné služby, rozvoje infrastruktury, rekreačních možností, sociální výměny, revitalizace místních tradic nebo image destinace. $\mathrm{Na}$ druhé straně obsahuje i negativní vlivy na tradiční hodnoty rodiny, komercionalizaci destinace, vzniku konfliktů kvůli odlišným ekonomickým podmínkám mezi místními a turisty a $\mathrm{v}$ dlouhodobém horizontu $\mathrm{k}$ závislosti destinace na turismu (Castillo Canalejo, Núñez-Tabales, Sanchez, 2016). Místní obyvatelé jsou jako první vystaveni prímému působení turismu, na jehož rozvoj 
mají minimální nebo nemají žádný vliv (Petra, 2010 in Al Rawabi et al., 2017). Stejně tak environmentální skupina zahrnuje negativní i pozitivní aspekty. Turismus může motivovat k ochraně a obnovování přírodního bohatství, na druhé straně jsou dokázány jasné negativní efekty, které turismus přináší (Samsul Alam, Paramati, 2016; Šolcová, Dysková, 2018).

\section{Základní data a informace o Maltě}

Maltské souostroví (tab. 1) leží v samotném srdci Středozemního moře (obr. 1), $93 \mathrm{~km}$ jižně od Sicílie a $288 \mathrm{~km}$ severně od Afriky. Celková rozloha země je $316 \mathrm{~km}^{2}$ a skládá se ze tří samostatných ostrovů, ležících v nevelké vzdálenosti od sebe (Visitmalta.com, 2018). Největším ostrovem je Malta, která je ekonomickým, sociálním a administrativním centrem země. Druhým z ostrovů Gozo je charakteristický větším zaměřením na zemědělství, turismus a rybářství. Comino, nejmenší z ostrovů ležící mezi dvěma zmíněnými, je prakticky neobydlený. Počet obyvatel Malty přesahuje 433000 , hustota zalidnění 1346,4 obyvatel $/ \mathrm{km}^{2}$, přičemž míra urbanizace dosahuje až $95 \%$ (UNDATA.org, 2018). Hlavní město země La Valletta je pro rok 2018 také evropským hlavním městem kultury.

Tab. 1: Základní údaje o Maltě

Table 1: Basic data about Malta

\begin{tabular}{|l|l||l|l|}
\hline Počet obyvatel & 431000 & Politický systém & parlamentní republika \\
\hline Rozloha & $316 \mathrm{~km}^{2}$ & Měna & euro (EUR) \\
\hline Hustota zalidnění & $\begin{array}{l}1346,4 \\
\text { obyvatel/km² }\end{array}$ & Náboženství & ř́msko-katolické $98 \%$ \\
\hline Hlavní město & La Valletta & Členství EU & 2004 \\
\hline $\begin{array}{l}\text { Počet obyvatel hl. } \\
\text { m. }\end{array}$ & 6089 & HDP země & 9747 mil. US\$ \\
\hline Úřední jazyk & $\begin{array}{l}\text { maltština, } \\
\text { angličtina }\end{array}$ & HDP/osoba & 23280,7 US\$ \\
\hline
\end{tabular}

Zdroj: vlastní zpracování, data: Euroskop.cz, online, 2018.

\section{Význam cestovního ruchu na Maltě}

Význam cestovního ruchu na Maltě je daný nejen její polohou, ale také podnebím, historií a potenciálem pláží. Neméně atraktivní jsou také tři lokality zapsané na seznamu světového kulturního dědictví UNESCO (Visitmalta.com, online, 2018). Stejně jako pro mnoho menších států nebo ostrovů je cestovní ruch velmi významný i pro maltskou ekonomiku. Př́mý příspěvek Travel \& Tourism na 
HDP země dosahuje $15,1 \%$ v roce 2017, což podle Travel \& Tourism Competitiveness Report (2017) znamená největší závislost na turismu ze všech zemí světa, celkový príspěvek turismu na HDP pak dosahuje až $27 \%$ s předpokládaným nárůstem o 2,7\% pro rok 2018 (The Travel \& Tourism Economic Impact 2018 Malta, 2018). Výdaje turistů pro rok 2016 dosáhly 1708,9 milionů euro, což znamená, že každý turista utratil přibližně 860 euro (Regional statistics Malta, 2017). Pro rok 2017 tvoří cestovní ruch 16,5 \% všech pracovních míst, zaměstnává tedy více než 29 tisíc lidí (Travel \& Tourism Competitiveness Report, 2017). Na druhé straně přesahují investice do cestovního ruchu $11 \%$ všech investic, s předpokládaným růstem $\mathrm{v}$ dalších letech (The Travel \& Tourism Economic Impact 2018 Malta, 2018).

Celkový počet zahraničních turistů, kteří Maltu navštívili (tab. 2), se mezi lety 2011 a 2016 zvýšil téměř o 40 \% na více než 1965000 (Regional statistics Malta, 2017), což znamená, že na každého místního obyvatele přijelo 4,5 zahraničního turisty. Podobnou dynamiku lze vidět i u počtu přenocování zahraničních turistů, které je pro rok 2016 necelých 14962 000, průměrná délka pobytu turisty je 7,5 nocí. Až 86 \% turistů je ze zemí EU, nejčastěji z Velké Británie, Itálie, Německa a Francie. Vzhledem k poloze je nejčastějším způsobem dopravy turistů do země doprava letecká, lodní využilo 2,4\% turistů (Tourism in Malta, 2016).

Tab. 2: Počet turistů a počet přenocování v letech 2011 - 2016

Table 2: Number of tourists and the number of overnight stays 2011 - 2016

\begin{tabular}{|l|c|c|c|c|c|c|}
\hline & $\mathbf{2 0 1 1}$ & $\mathbf{2 0 1 2}$ & $\mathbf{2 0 1 3}$ & $\mathbf{2 0 1 4}$ & $\mathbf{2 0 1 5}$ & \multicolumn{2}{c|}{$\mathbf{2 0 1 6}$} \\
\hline Turisté & 1415018 & 1443414 & 1582153 & 1689809 & 1783366 & 1965928 \\
\hline Přenocování & 11241472 & 11859521 & 12890263 & 13522112 & 14151599 & 14961366 \\
\hline
\end{tabular}

Zdroj: vlastní zpracování, data: Regional Statistic Malta, 2017

K největším lákadlům Malty patří kultura a slunce, minoritní roli hraje návštěva přátel a př́buzných, business nebo sportovní vyžití (Tourism in Malta, 2016). Navzdory tomu, že úředním jazykem Malty je i arabštině podobná maltština, běžným dorozumívacím i vyučovacím jazykem na školách je angličtina. Její výuka rozšiřuje turistickou nabídku souostroví. Během roku 2017 vzrostl počet turistů přijíždějících za tímto jazykem ze 76300 (Tourism in Malta, 2016) o 13,6 \% na 87000 studentů. Segment jazykového vzdělávání tvoří podle FELTOM Association 10,4\% podíl na celkovém počtu přenocování zahraničních návštěvníků (Pace, 2018). 
Obr. 1: Poloha Malty

Figure 1: The location of Malta

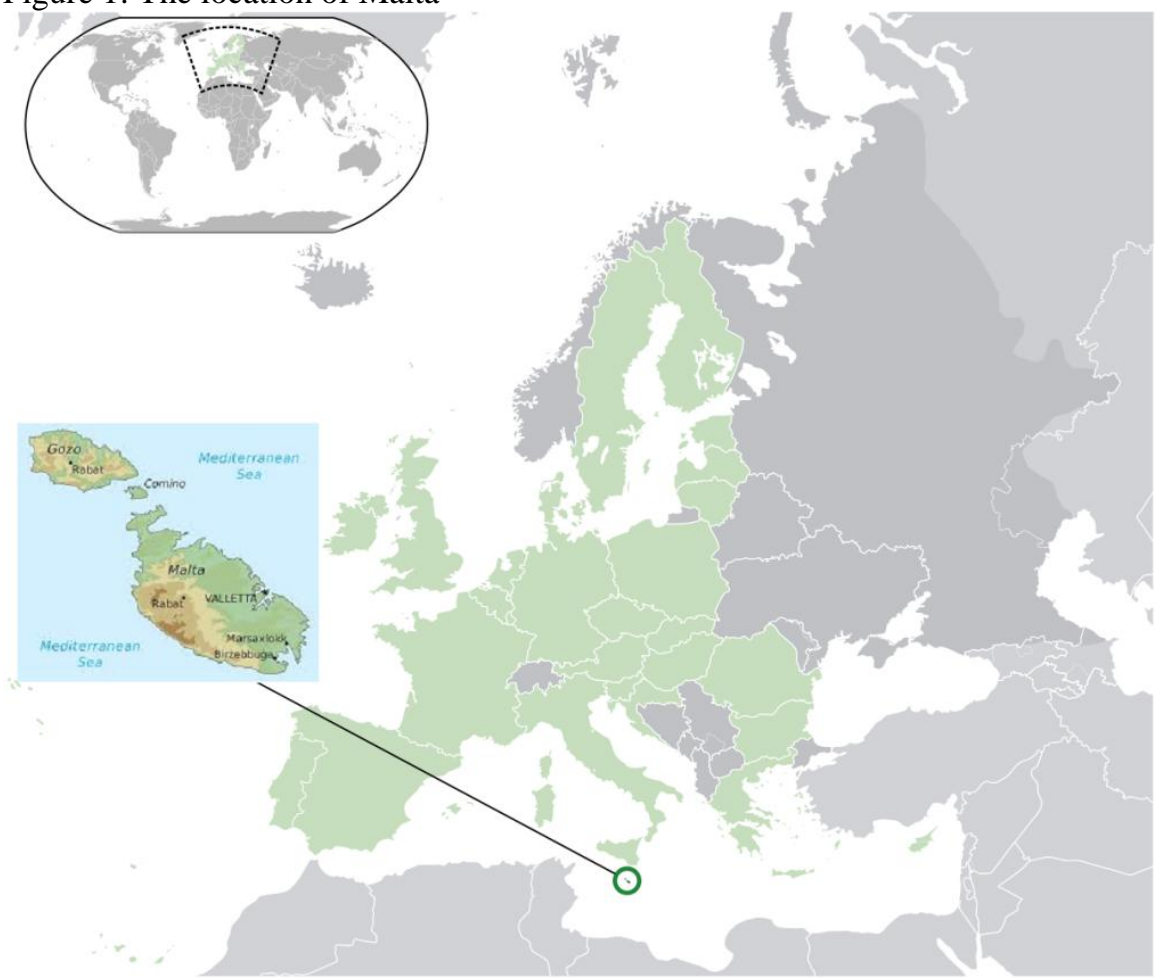

Zdroj: vlastní zpracování, podklad Wikimedia Commons

\section{Metodologie}

Jednou z běžných metod výzkumu postojů rezidentů vůči cestovnímu ruchu, vnímání jeho vlivu a celkové problematiky, je využití dotazníkové metody. Pro tuto práci byl využit dotazník zaměřený na subjektivní vnímání vlivu cestovního ruchu na destinaci.

Cílovou skupinou šetření byli obyvatelé Malty do 26 let, jejichž výběr byl náhodný, podmínkou byla znalost angličtiny a věk nad 18 let, nebot' dotazník byl v anglickém jazyce. Vzhledem k tomu, že nebylo možné pokrýt celou plochu státu, byl výzkum soustředěný do oblasti Salina. Respondenti, kteří souhlasili s účastí na šetření, dostali dotazník, přičemž ve většině př́padů ho individuálně vyplnili ihned, v prrípadě nejasností bylo podáno vysvětlení. $\mathrm{V}$ př́ípadě pozdějšího vyplnění byly dotazníky sesbírány v průběhu dalších dnů osobně nebo byla domluvena možnost jejich zanechání v kanceláři ESE (European Students of English) v resortu Salini. 
Celkem bylo mezi 13. 8. až 28. 8. 2018 získáno 93 plně vyplněných dotazníků ze 120 rozdaných, návratnost je tedy $77,5 \%$.

Dotazník se skládal ze tří částí. První zaměřená na socioekonomické charakteristiky obsahovala otázky týkající se pohlaví, věku, zaměstnání, rodinného statutu a vzdělání. Druhá část, věnovaná vnímání vlivu turismu na socioekonomické oblasti Malty, obsahovala 23 otázek. Pro platnou odpověd' bylo třeba zaznačit hodnotu od -5 do -1 pro negativní vliv, od 1 do 5 pro pozitivní vliv s tím, že hodnota -5 odpovídá velmi negativnímu vlivu, hodnota 5 velmi pozitivnímu vlivu a hodnota 0 odpovídá žádnému/nulovému vlivu, vždy s možností doplnění vlastního komentáře. Třetí část obsahovala otázky s možnostmi odpovědí od 1, pro minimální, do 5, pro velký význam, opět s možností doplnění vlastního komentáře.

Pro základní analýzu dat byly využity průměry jednotlivých odpovědí a následně průměrné hodnoty pro ekonomickou, sociální, kulturní a environmentální kategorii. Pro identifikování vlivu sociodemografických proměnných na jednotlivé kategorie byly využity kontingenční tabulky programu MS Excel.

\section{Výsledky a diskuse}

Jak je možné vidět $\mathrm{z}$ tab. 3, která se váže $\mathrm{k}$ sociodemografickým charakteristikám respondentů, výzkumu se zúčastnil relativně vyrovnaný počet žen a mužů převážně pocházejících z Malty. Významnou proměnnou je vzdělání, kdy je patrné, že naprostá většina dotazovaných dosáhla minimálně bakalářského stupně vzdělání, jen necelých $20 \%$ má ukončené vzdělání stř̌edoškolské. Nicméně je třeba brát ohled na skupinu respondentů do 20 let, kteř́ mohou univerzitu studovat nebo na ni nastoupí až v následujícím roce. Navzdory tomu až $44 \%$ dotazovaných je aktuálně zaměstnaných a $56 \%$ se věnuje pouze studiu. Dvě třetiny respondentů jsou single, jedna třetina žije s partnerem nebo v manželství.

$\mathrm{Na}$ základě rešerše literatury byly vybrány jednotlivé prvky pro skupiny ekonomickou, environmentální, sociální a kulturní, které jsou uvedeny v tab. 4, společně s výsledky pro jednotlivé skupiny. Ty ukazují obecně negativně vnímaný vliv turismu na prostředí Malty. Vliv na jednotlivé skupiny mají sociodemografické charakteristiky, přičemž ženy hodnotily jednotlivé skupiny, s výjimkou kulturní, výrazně negativněji než muži. Stejně tak i dotazovaní s nejvyšším dosaženým středoškolským vzděláním hodnotili vlivy negativněji, u skupiny kulturní výrazně pozitivněji, než další účastníci výzkumu.

Nejsilněji se projevuje působení cestovního ruchu na environmentální skupinu, ve které žádný $\mathrm{z}$ prvků nebyl v průměrné hodnotě hodnocen pozitivně. Nejproblémovější se ukazuje vliv turismu na dopravní zatížení Malty, znečištění a odpadky. Navzdory očekávání a problematice vodního hospodářství Malty není turismus vnímán jako zatěžující faktor. Přitom více než $14 \%$ veškeré pitné vody je spotřebováváno turisty, $\mathrm{z}$ toho více než $85 \%$ tvoří spotřeba zahraničními turisty a 
země se tak řadí na druhé místo z evropských zemí, za Kypr (Styles, Schönberger, Galvez Martos, 2013).

Tab. 3: Sociodemografické charakteristiky

Table 3: Socio-demographic characteristics

\begin{tabular}{|c|c|c|}
\hline Proměnná & Kategorie & Procenta \\
\hline \multirow{2}{*}{ Pohlaví } & Žena & $44 \%$ \\
\hline & Muž & $56 \%$ \\
\hline \multirow{2}{*}{ Věk } & Pod 20 let & $28 \%$ \\
\hline & $20-26$ let & $72 \%$ \\
\hline \multirow{2}{*}{ Původ } & Narození na Maltě & $78 \%$ \\
\hline & Trvale žijící na Maltě & $22 \%$ \\
\hline \multirow{5}{*}{ Vzdělání } & Bez vzdělání & $0 \%$ \\
\hline & Základní & $0 \%$ \\
\hline & Stř̌edoškolské & $19 \%$ \\
\hline & Vysokoškolské & $75 \%$ \\
\hline & Jiné & $6 \%$ \\
\hline \multirow{4}{*}{ Zaměstnání } & Student & $56 \%$ \\
\hline & Zaměstnaný & $44 \%$ \\
\hline & Nezaměstnaný & $0 \%$ \\
\hline & Jiné & $0 \%$ \\
\hline \multirow{4}{*}{ Rodinný stav } & Single & $69 \%$ \\
\hline & S partnerkou/partnerem & $28 \%$ \\
\hline & Vdaná/ženatý & $3 \%$ \\
\hline & Jiné & $0 \%$ \\
\hline
\end{tabular}

Zdroj: vlastní zpracování

Ekonomická stránka je silně ovlivněná prvkem nabídky práce. Jak již bylo zmíněno dříve, turismus tvoří až $16,5 \%$ pracovních míst, není tedy překvapující, že jeho vliv na nabídku práce je hodnocený velmi pozitivně a s rozdílem až 1,4 bodu pro současné studenty oproti pracujícím. Pozitivně je také hodnocen vliv turismu na diversitu nabídky zboží a služeb. Na druhé straně pak stojí otázky ceny bydlení, která je podle odpovědí vnímána velmi negativně. Tomuto odpovídají i zjišsění 
SET`s (Southern European front against Touristification), jejichž zpráva mimo jiné zmiňuje problémy místních způsobené zkupováním nemovitostí společnostmi za účelem jejich využití pro turisty (Costa, 2018). Stejně tak jsou negativně ovlivněny i ceny zboží a služeb, přičemž Tkalec a Vizek (2016) dokládají, že cestovní ruch zvyšuje celkově ceny v ekonomice, tento efekt je nicméně mnohem silnější ve službách zákazníkům, konkrétně rekreace, kultura, hotely a restaurace.

Tab. 4: Skupiny a výsledný vnímaný vliv cestovního ruchu na tyto skupiny Table 4: Categories and the resulting perceived impact of tourism on these groups

\begin{tabular}{|l|r|r|}
\hline \multicolumn{1}{|c|}{ Skupina } & Zahrnující: & Průměr \\
\hline \hline Ekonomická & $\begin{array}{r}\text { pracovní příležitosti, ceny bydlení, } \\
\text { produktů a služeb, diversitu produktů a } \\
\text { osobní př́imy }\end{array}$ & $-0,391$ \\
\hline Environmentální & $\begin{array}{r}\text { dopravu, odpady, znečištění, hluk, } \\
\text { množství odpadků, vodní hospodářství a } \\
\text { jeho ř́zení a krajinu }\end{array}$ & $-2,183$ \\
\hline Sociální & $\begin{array}{r}\text { public management, kvalitu služeb, } \\
\text { kriminalitu, vandalismus, fronty v }\end{array}$ & 0,010 \\
\hline Kulturní & $\begin{array}{r}\text { obchodech a dalších zařízeních, standard } \\
\text { bydlení a subjektivní kvalitu života. }\end{array}$ & \\
\hline
\end{tabular}

Zdroj: vlastní zpracování

Na sociální oblast má turismus již mírně pozitivní vliv, přičemž hodnoty průměru se pohybují od $-0,625$ do 0,625 , tyto dvě hodnoty konkrétně pro negativní vliv turismu na kriminalitu a vandalismus v zemi. Jako pozitivní je vnímán tlak cestovního ruchu na zvyšování kvality zboží a služeb. Pro další prvky je vidět jen malý rozptyl hodnot odpovědí, z čehož lze vyvodit, že vliv na tyto prvky je pouze minimální.

Jako jednoznačně pozitivní se ukazuje vliv cestovního ruchu na kulturní skupinu a to především v péči a rozvoji kulturního dědictví země. Toto může být ovlivněno současným posílením image Valletty jako evropského hlavního města kultury a s tím souvisejícím bohatým kulturní program nejen v tomto městě (Visitmalta.com, online, 2018). Na toto jsou navázané i další kulturní prvky, jako je např. zachovávání a obnova tradic a zvyků. 
Tab. 5: Výsledky výzkumu pro vybrané otázky

Table 5: Research results for selected questions

\begin{tabular}{|l|r|}
\hline & \multicolumn{1}{|c|}{ Průměr } \\
\hline \hline Existuje v zemi problém overtourismu? & 3,688 \\
\hline Existuje v zemi problém tourism-phobie? & 2,688 \\
\hline Je země závislá na cestovním ruchu? & 4,156 \\
\hline Je tato závislost problémem? & 3,313 \\
\hline Je země "overcrowded" kvůli turistům? & 4,031 \\
\hline
\end{tabular}

Zdroj: vlastní zpracování

Navzdory tomu, že počet turistů, který navštíví zemi každý rok, několikanásobně přesahuje počet místních obyvatel, média reportují, že na Maltě doposud nevzniká problém overtourismu, tak jako např́klad v Benátkách, Dubrovníku nebo Barceloně (O`Toole, 2018). Na druhé straně se ale objevují tendence $\mathrm{k}$ vytvoření horní hranice počtu turistů, která je pro Maltu př́pustná z hlediska velikosti a vysokého zalidnění (Micallef, 2018). Jak vyplývá z výzkumu (tab. 5), je jasně vidět, že pro mladé je množství turistů, kteři se v destinaci pohybují, již nad hranicí únosnosti a země je v důsledku vysokého počtu turistů overcrowded. Výsledky dotazníkového šetření ukazují, že cílová skupina mladých do 26 let v zemi problém overtourismu vnímá a do jisté míry vnímají i problém tourism-phobie. Tato nicméně není tak vysoká, důvodem může být, že po celé generace jsou Malt’ané zvyklí vítat cizince a nabízet jim pohostinnost (O`Toole, 2018). Je zřejmé, že si dotazovaní uvědomují, že země je závislá na cestovním ruchu a tuto závislost vnímají jako silný a specifický problém.

\section{Závěr}

Cestovní ruch přináší do destinace nejen pozitivní, ale také negativní vlivy. Jejich vnímání místními a pochopení jejich důsledků je klíčové pro udržitelný management destinace. Pro tento př́spěvek byla zvolena Malta, jako země nejvíce hospodářsky závislá na cestovním ruchu na světě. Výsledky výzkumu ukazují, že mladí do 26, na které byl výzkum zaměřen, tuto závislost vnímají a považují za problém, se kterým se země bude muset potýkat. V návaznosti na toto silně vnímají i problémy, které s sebou turismus přináší a to zejména $\mathrm{v}$ environmentální oblasti. Stejně tak některé ekonomické prvky a sociální jsou cestovním ruchem negativně ovlivněny, v kulturní oblasti převládá vliv pozitivní. Postoj místních je nezbytnou veličinou, která musí být zohledněna, pokud má být rozvoj destinace udržitelný. $Z$ tohoto důvodu je potřeba nejen výzkum rozšírit, ale také najít 
srovnání s dalšími místy, které se mohou stát inspirací pro řešení problémů, které s sebou cestovní ruch přináší.

\section{Poděkování}

Tento př́spěvek byl zpracovaný v rámci projektu Města, obce, regiony: management, procesy a interakce $v$ teorii a praxi (MUNI/A/0994/2017).

\section{Literatura}

AL RAWABI, T. et al. 2017. The Price Tag of Tourism: Does Tourism Activity Increase the Prices of Goods and Services?. In Tourism Economics. 2017, vol. 2, no. 3 .

ANDEREK, K. L. et al. 2005. Overtourism: Residents` perceptions of community tourism impact. In Annals of Tourism Research. 2005, vol. 32, no. 4.

BIMOTE, S. - FARALA, V. 2016. Does residents' perceived life satisfaction vary with tourist season? A two-step survey in a Mediterranean destination. In Tourism Management. 2016, vol 55, no. 3.

CASTILlO CANALEJO, A. M. - NUÑEZ-TABALES, J. M. - SANCHEZ, S. 2016. Local Community Perceptions on Tourist Impacts and Associated Developments: A Case study on Sal and Boa Vista Islands. In Mediterranaean Journal of Social Sciences. 2016, vol. 7, no. 1.

COSTA, M. 2018. Even in Malta, the fights against mass tourism starts gathering steam. In Maltatoday.com [online]. [cit. 2018-09-13]. Dostupné na internete: https://www.maltatoday.com.mt/environment/environment/88092/even_in_mal ta_the_fight_against_mass_tourism_starts_gathering_steam\#.W6CrRfmYRxB

DATA. UN.ORG. 2018 [online]. [cit. 2018-05-21]. Dostupné na internete: http://data.un.org/

DOWLING K. R. - NEWSOME, D. 2017. Geotourism Destinations - Visitor Impacts and Site Management Consideration. In Czech Journal of Tourism. 2017. vol 6, no. 2.

GENG GING-CHI, C. et al. 2017. Factors influencing residents' subjective wellbeing at World Heritage Sites. In Tourism management. vol. 63, pp. 209-222.

GONZALES V. M. - COROMINA, L. - GALÍ, N. 2018. Overtourism: Residents` perceptions of tourism impact as an indicator of resident social carrying capacity - case study of a Spanish heritage town. In Tourism Review. 2018, vol. 73 , no. 3 .

GURSOY, D. - CHI, G. G. -DYER, P. 2010. Locals Attitudes toward Mass and Alternative Tourism: The Case of Sunshine Coast, Australia. In Journal of Travel research. 1998, vol. 19, no. 3.

KLUFOVÁ, R. - ŠULISTA, M. 2018. Perception of Czech Rural Life by its Inhabitants in Connection to Tourism. In Deturope. 2018, vol. 10, no. 1. 
KOENS, K. Dealing with overtourism in European Cities. Bolzano: Breda University, 2018.

LAWSON, R. W. et al. 1998. A comparison of residents` attitudes towards tourism in 10 New Zeeland destinations. In Tourism Management. 2017, vol. 63, no. 3.

MICALLEF, K. 2018. PM says MHRA`s overtourism concerns are almost ironic. In Times of Malta [online]. [cit. 2018-05-21]. Dostupné na internete: https://www.timesofmalta.com/articles/view/20180520/local/pm-says-mhrasover-tourism-concerns-are-almost-ironic.679539

MILANO, C. 2017. Overtourism and Tourismphobia: Global trends and local contexts. The Ostelea, 2017.

O`TOOLE, CH. 2018. Breaking Travel News investigates: Tourism in Malta. In Breaking Travel News.com, 2018 [online]. [cit. 2018-05-21]. Dostupné na internete: http://www.breakingtravelnews.com/focus/article/breaking-travelnews-investigates-tourism-in-malta/

PACE, F. 2018. 87000 foreign students came to Malta to study English. In tvm.com 2018 [online]. [cit. 2018-05-21]. Dostupné na internete: https://www.tvm.com.mt/en/news/87000-foreign-students-came-to-malta-tostudy-english/

REGIONAL STATISTIC MALTA. 2017 [online]. National Statistics Office, 2017. 307 p. ISBN 978-99957-29-62-2 [cit. 2018-05-21]. Dostupné na internete: https://nso.gov.mt/en/publicatons/Publications_by_Unit/Documents/02_Region al_Statistics_(Gozo_Office)/Regional\%20Statistics\%20MALTA\%202017\%20 Edition.pdf

REISINGER, Y. 2009. International Tourism Cultures and Behaviour. Burlington: Elsevier, 2009. 450 p. ISBN 978-07506-7897-1.

SAMSUL ALAM, M. - PARAMATI, S. R. 2016. The impact of tourism on income inequality in developing economies: Does Kuznets curve hypothesis exist?. In Annals of Tourism Research. 2016, vol. 61, pp. 111-126

STYLES, D. - SCHÖNBERGER, H. - GALVEZ MARTOS, J. L. 2013. Best Environmental Management Practice in the Tourism Sector [online]. European Commission, 2013. 721 p. [cit 2018-09-17]. Dostupné na internete: http://ec.europa.eu/environment/emas/pdf/other/TourismBEMP.pdf

ŠOLCOVÁ, L. - DYSKOVÁ, S. 2018. Economic, spatial and environmental aspects of growing geotourism in island Iceland. In Klímová, V., Žítek, V. (eds.) XXI. mezinárodní kolokvium o regionálních vědách. Sborník příspěvků. Brno: Masarykova univerzita, 2018. s. 595-602. ISBN 978-80-210-8969-3.

THE TRAVEL \& TOURISM COMPETITIVENESS REPORT 2017. [online]. World Economic Forum 2017. 387 p. ISBN 978-1-9448835-08-8. Dostupné na internete: http://www.sela.org/media/2756841/the-travel-and-tourism-competti veness-report-2017.pdf

THE TRAVEL \& TOURISM ECONOMIC IMPACT 2018 MALTA. 2018 [online]. World Travel and Tourism Council 2018. 24 p. [cit. 2018-05-21]. 
Dostupné na internete: https://www.wttc.org/-/media/files/reports/economicimpact-research/countries-2018/malta2018.pdf

TKALEC, M. - VIZEK, M. 2016. Resudents Perception of Tourism Impacts in A Dhakhiliyah Region of Sultanate of Oman. In Journal of Tourism and Managament Ressearch [online]. 2016, vol. 2, no. 3.

TOURISM IN MALTA. 2016. Malta Tourism Authority, 2016. 16 p.

VISITMALTAONLINE. COM. 2018 [online]. About Malta [online]. 2018 [cit. 2018-05-21]. Dostupné na internete: https://www.visitmalta.com/en/aboutmalta

VISITMALTAONLINE. COM. 2018 [online]. European Capital of Culture [online]. 2018 [cit. 2018-05-21]. Dostupné na internete: https://www.visitmalta.com/en/european-capital-of-culture-2018

WALL, G. - MATHIESON, A. 2006. Tourism, Change, Impacts and Opportunities. Pearson Education Limited, 2004. 412 p. ISBN 978-0-13099400-4.

WEBER, F. et al. 2017. Tourism destination under pressure. Challenges And Innovative Sollutions. Hochschule Luzern.

WIKIMEDIA COMMONS, 2018. Location European nation states.svg. Dostupné na internete: https://commons.wikimedia.org/wiki/File:Location_European_nati on_states.svg

\section{THE IMPACT OF TOURISM ON SOCIO-ECONOMIC AND ENVIRONMENTAL SPHERE OF MALTA: THE PERCEPTION OF YOUNG PEOPLE}

\section{Summary}

Tourism is one of the most rapidly growing areas with significant, both positive and negative, economic, environmental, social and cultural impacts (Andereck et al. 2005). Its growth and sustainable development are becoming challenge for destinations all over the world. Recently, media has been informing about places that are confronted with the issue of overtourism and tourism-phobia. One of the key parts not only of overtourism is the relationship between locals and tourists, the understanding of attitudes and perceptions of tourism by residents are the basis for its sustainable development regardless of the form in any destination (Gursoy, Chi, Dyer, 2010).

Malta consists of three separate islands - Malta with the capital city La Valleta, Gozo and Comino, the number of inhabitants exceeds 433000 . The importance of tourism is given not only by the location of the country, but also by climatic conditions and history. The direct contribution of tourism to GDP is 15\%, total contribution exceeds $27 \%$ with expected growth $2,7 \%$ for the next year (The Travel \& Tourism Economic Impact 2018 Malta, 2018). In 2017, tourism created 
more than $16,5 \%$ jobs. These numbers according to the Travel \& Tourism Competitiveness Report (2017) signify the highest country`s dependence on tourism in the world.

The research focused on young people up to the age of 26 , based on questionnaire survey the subjective attitudes and opinions of respondents on the impacts of tourism, were investigated. In total, 93 correctly filled questionnaires were used for analysis. The results show similar number of men and women with significant $(80 \%)$ dominance achieved university education, $44 \%$ of respondents are currently employed, $56 \%$ are students, two thirds of respondents are single, one third lives with a partner or in marriage.

Based on literature review the components of economic, environmental, social and cultural groups were depicted. They are together with the overall result of perception shown in the table 1 . The construct of the value is given by the options of answers ranging from -5 for very negative impact to 5 for very positive impact, with 0 for no impact. From the results, it is clear tourism has the most negative impact on the environmental group in which no single element was rated positive. Also economic site is rated negative. In this group the element of job offers stands out and as high number of people are employed in the tourism industry, it is not surprising that this one is rated very positive. On the other hand, the influence of tourism on the prices of living and costs of goods and services is strongly negative. Within the social group, the influence is negative on criminality and vandalism, positive on pressure on quality of goods and services and overall rated slightly positive but in general the impact is minimal. We can state tourism has a positive impact on cultural group, mostly on the keeping and the cultural development of the country.

Other results show negative perception of Malta`s dependence on tourism, existence of overtourism and partly, but not so significant, problem of tourismphobia. Clearly stated is that the number of tourists in the country has exceeded the acceptable limit. Hence the streets are overcrowded due to tourists and this may lead to future social problems. Solving this is going to be a key for sustainable development of the country in the future.

\section{Ing. Aneta Krajíčková}

Katedra regionálního rozvoje a správy

Fakulta ekonomicko-správní

Masarykova univerzita

Lipová 41a, 60200 Brno

E-mail: Aneta.Krajíčková@mail.muni.cz 